\title{
The Resilience of Women Who Are Divorced and Choose to Live with Their Children
}

\author{
Muhammad Haikal", Latipun Latipun \\ Department of Psychology, University of Muhammadiyah Malang, Malang, Indonesia \\ Email address: \\ haikal.psikologiklinis@gmail.com (M. Haikal), latipun@umm.ac.id (L. Latipun) \\ ${ }^{*}$ Corresponding author
}

\section{To cite this article:}

Muhammad Haikal, Latipun Latipun. The Resilience of Women Who Are Divorced and Choose to Live with Their Children. Psychology and Behavioral Sciences. Vol. 9, No. 4, 2020, pp. 44-49. doi: 10.11648/j.pbs.20200904.12

Received: June 5, 2020; Accepted: July 7, 2020; Published: July 17, 2020

\begin{abstract}
Divorce is an unexpected condition that might happen to people and has been experienced by some married people. Unfortunately, some women face a lower quality of life after divorce, such as economic problems, lifestyle, and even bad social relationships. On the contrary, other women could be more productive and independent after divorce. The current study aims to explore how resilience, ability to adapt, and stay unwavering under challenging times for divorced women, especially for those who have not remarried after five years of divorce. The researcher used a qualitative approach, and data collected with deep interview method and observation. This research analyzes based on the exploration of how divorce could happen and discover ineffective communication as the main reason for a divorce. Social support is primarily needed, including supports from family and best friends. They have "hope" to build their own business and patience to control their emotion after divorce, and then take lessons from it. They also endeavor to pride themselves as individuals who could be independent and be better in the future.
\end{abstract}

Keywords: Resilience, Wife, Divorce, Communication, Family

\section{Introduction}

Marriage is a sacred activity that could bring happiness to anyone dealing with it. Having a happy family is a dream for everyone, yet not all people could reach it. Building a family is similar to sailing a boat. It needs good cooperation with each other to make it work correctly [1]. On the other hand, creating a family is natural for adult people, both men, and women. Family is a social system that contains two or more people to live together. A right family could be built based on blood, marriage, adoption, living together, having children, mutual understanding, and loving each other to reach the family's goal [2].

Based on the current development, human attitudes change, especially in terms of communication with their spouses. In general, most people communicate through social media to forget to communicate with the people around them. Some people often ignore communication among families, which could lead to divorce. As we know, divorce is an unwanted condition that should be avoided by married couples [3], especially since one of the goals in a marriage is to create a happy family. Some factors make people divorces, such as economic difficulty, lack of proper communication, social influence, or third person. Even though religion and country allow people to divorce, but some cultures valued, it is a social problem [4].

Individuals tied by marriage sometimes have a problem that leads them to divorce. There are other factors rather than an economic issue: non-smooth communication, third person, domestic violence, unfulfilled physical needs, and social impact. Divorce is a symbol of failure, according to society's opinion. People tend to think that when a couple decides to divorce, it indicates that there must be huge problems between them.

Divorce cases in Indonesia from time to time continue to increase. Families who register in the court to file for divorce continue for various reasons. In the community, many families are found divorce

$\mathrm{d}$ but not through litigation and recorded in the state. The incidence of cases indicates that there are social problems within society. Divorce impacts are not pleasant for each spouse, especially the wife, who has a social burden to 
support her family [5].

According to the previous study by Scoot et al. [6], that the high amounts of divorce are caused by several factors like poor communication, irresponsible husband, economic crisis, nonexistent of positive behavior, third person, or domestic violence. Sadly, the number of divorces is getting higher every year. This condition is the main issue for the Indonesian community. A divorce reflects a minimum understanding of a woman's rights as a wife. Therefore, a woman's independent habit becomes one of consideration to decide whether to end or continue their household.

Psychologically, women are prone to face psychological problems than men after getting divorced. Women tend to be judged as an emotional, quitter, surrender, subjective, and non-independent individuals, otherwise, men as more rational, logical, independent, aggressive, competitive, and objective [7]. These factors influence the psychological aspect of divorce offenders. Every human will face an unpleasant moment in their life. When their expectation is not suitable with reality, people could face depression or pressure within themselves [8].

Divorce is not only a minor problem but can also be a severe problem for some divorced people. Many people feel anxious, get high pressure, depression, anger, or lack of confidence to survive after divorce [9]. People accused women of divorce victims because of the community believes that a wife can not live well without the husband's role. In the current era, the negative prejudice toward divorced women is not appropriate. Some women could survive after getting divorced and live a better life than their marriage life [10].

Bold, strong, and independent women are needed in this era. Today, women also have the opportunity to work and financial resources like men. Many cases showed divorced women who could be more productive to live around their environment because of their high spirits and positive attitudes. Some women faced uncomfortable moments after divorce, but it does not mean that they are weak. It is because of their motivation to live and continue their lives. This type of woman usually focuses more on finishing problems and long term development, such as being a strong woman for their beloved kids. [11] These positive minds appear after a long process in their life, especially after experiencing a hard moment of divorce, which could turn them into a better individual, more robust, bolder, braver, and more mature to deal with reality. They try to rise from failure, and this is called resilience.

Self-resilience is when a person can get through an unstable process, and psychologically, he or she can develop himself or herself to be a better person. Besides, selfresilience is the ability to adapt, stay healthy, firm, and overcome all difficulties in their lives [12]. In many cases, life's difficulties are a source of anxiety and other emotional problems. However, in this study, divorced women continue to struggle alone without the role of their husbands again, to resolve various matters of their lives.
It is interesting to analyze the phenomenon, especially in the era where society tries to survive with any limitations like job vacancy, education, and health. Hopefully, this research could contribute to the readers, especially divorced women who tried to live independently. This research is expected to understand the positive and negative possibilities before and after getting married.

\section{Material And Methods}

\subsection{Research Design}

Qualitative design, phenomenological to answer the object of study by using a semi-structured interview.

\subsection{Subject of Study}

This research used networks and snowballs as subjects. Snowball functions to help to find candidates who could provide crucial information for the researcher. This research used five subjects; they were women who have divorced for more than five years, and they have not yet found a new spouse. They are more than 20 years old and live in Malang, East Java.

\subsection{Procedure}

The researcher selected the sample based on the snowball method. The researcher did it step by step from the first subject to the fifth subject. Before collecting the data, the researcher prepared all methods and documents, such as the interview guide and informed consent. The data was processed by giving informed consent as an agreement to keep the subject's identity confidential. The researcher also made an appointment before delivering the informed consent to the subjects. After that, the semi-structured interview was conducted by providing a flexible list of questions. The interviewer conducted an in-depth interview until he got clear answers.

\subsection{Data Analysis}

This research uses thematic analysis. Data is collected through interviews and observations and then transcribed. Data were analyzed by organizing data, categorizing them based on themes, and finally, applying data analysis and interpretation.

\section{Result}

Based on the data analysis, five themes of why wives decided to divorce their husbands. It showed support, hopes, and attention from other people. Subjects had a willingness for their long term life's plan by being patient with the condition they faced. Lastly, pride involved how subjects interpret themselves as individuals who could be independent and better people for their future lives. 


\subsection{Similar Communication Pattern Which Causes Divorce}

Almost all subjects had similar backgrounds of why they divorced. It was because of an inharmonious communication pattern. As a reminder, communication refers to two ways communication like what M said:

"We are seldom to talk now. Since the beginning, we had a bad communication pattern. Before marriage, everything was fine although we were busy enough with our own business". If we talk about a problem, it always exists. Moreover, my husband was a lazy person. After he arrived home, we kept silent. As a result, we rarely communicated to each other".

Communication can be a mediation between husband and wife to exchange their minds and affections. Unfortunately, sometimes married couple abandons it. If a married couple has opened their mind to each other, it could create a harmonious atmosphere during their household.

\subsection{How Crucial Others Support}

Supports from family is a significant factor in surviving after getting divorced, as $\mathrm{T}$ said:

"As a human being, I felt sad and disappointed with that guy, but I still had friends and families who support me. My brother in law was the closest person for me and my child. They played together during weekends. My mother always gave me suggestions to keep close to God."

Supports are not only from family but also from relatives and society. It is vital for someone who faced difficulties. For divorced people, this kind of support is a primary factor in raising and growing to be an independent person. Since it is not easy for widows to keep thinking positively after divorced, therefore support from others is needed.

\subsection{Future Wishes}

Each person has different wishes to reach in life. They do it to keep their spirit for their future, as B said:

"I lost my spirit after divorcement, but my kids make me stronger. So, I want to change to be a better person. I want to do Umrah with my children if our business goes well. Then, if God allows me to have a good spouse who could accept the way I am, I will consider getting married again. But I should be more careful now".

The future hope is the most essential factor after facing an unpleasant thing like divorcement. When someone has a high spirit, anything can be their power to continue their lives full of hope and beliefs. Those five subjects could not go this far unless they have firm future wishes inside their hearts. Maturity, independence, and commitment are some factors to be a successful person.

\subsection{Endurance}

Subjects who faced divorcement have the endurance to make them be a better person than before since they can accept themselves as much as they can. Like what L said:

"I want to consider it as Muhasabah for myself. I want to bury these problems, or I could not forgive my self. I will always be anxious and think negatively. It was difficult at the beginning, but we need a process. Now I can face anything that might happen in the future. I am ready to accept it because I believe this is the best for me, isn't it?."

According to this case, we can tell that endurance can make someone be more grateful and appreciate their life after a massive disaster. As a result, they can live their life productively.

\subsection{High Self Esteem}

Self-esteem is a notable factor for people who got divorced. J said:

"I could work and build a business without a husband since I was young. I have sold something. I imitated my grandmother, so it was not scary for me because of the strong belief that I can work by myself. After I got married to him, I became a seller with my ex-husband even though we decided to divorce in the end. I still have confidence in my skills. Moreover, I have kids, and they always help me out after they go home."

It is prominent to consider herself as a healthy person to face many disasters. Being a braver and independent person is a must to survive in the future. Someone who can appreciate themselves positively will be able to live their life full of hope and willingness to be a successful person.

\section{Discussion}

Those five subjects decided to divorce their husband due to the same poor communication pattern. Otherwise, the other subjects decided to divorce because of the third-person. $M$ settled to separate from her husband. On account of difficulties, she kept communicating with her ex-husband. She also tried her best to fix their communication pattern, but it failed. Most of the wives had inharmonious communication. On the contrary, $\mathrm{T}$ and $\mathrm{B}$ explained that their communication pattern got bad after their husbands moved out to work in another city. On the other hand, L said, third-person existence is a significant cause of their divorcement.

Married couples should maintain communication during their household to create good interaction. If they do not have healthy communication, it can cause serious conflict. It depends on their communication, whether it goes well or not. It can impact their family's happiness. It can make them happy if healthy communication exists within their household. [13] Husband often ignores communication since both husband and wife have their businesses. It makes them rare to meet each other. As explained previously, communication plays an essential role in the conflict of their household. [4] Otherwise, J said that third person existence is her primary reason to end her marriage. An affair often happens to a married couple. It is also the primary trigger of divorcement [15].

Those five subjects faced reverse after their divorcement with their ex-husband, such as stress and fears of social judgment. As time flies, they can rise from failure and try to be a new and stronger person to raise their children. Wives 
need to have these characteristics to be an independent person to get through from their awkward moments. It also helps them to understand themselves positively. Both independent and favorable characteristics are crucial. Five subjects can look up and appreciate their lives as positive as possible. Their resilience supports it. It is called effort and willingness to survive psychologically and function a stable stage and a healthy life after a conflict [16].

Resilience needs a long process and a hard effort to consider someone as an independent and successful person. Here are exciting things related to how wives can live separately from their ex-husbands and grow as a strong and firm woman [17]. Each person wants to get attention from others. Supports from family or environment are essential to help them grow stronger, braver, and more patience. Affection and support from others can make them feel comfortable and safe [18]. M and J got support and affection from their family, although at first, their family opposed their decision. As time goes, M and J's family could accept their conditions. They also got support from their husband's family. Their support makes them more confident. Proper supports become the right pillars for the subjects to be better women.

On the contrary, $\mathrm{T}$ and $\mathrm{L}$ did not get support from their family. Fortunately, they got support from their friends. According to L, friends' supports are the best thing to rise from the worst level of her life. She preferred to share stories with her friends than with her family. Otherwise, B got support from her ex-husband. Although they have been separated from each other, they still had a good relationship. Subjects took advantage of support from the people around them. It showed the positive impact of support for them. It can make them improved even better and more independently. Those five subjects grew as new and exempt characters. T, L, and $\mathrm{B}$ explained that they have been exempt since the beginning; they built their household with a part-time job.

Their exempt characteristics appeared after they got support from friends and family. At the same time, they also had a desire within themselves. It is the most noteworthy thing. L said that she wanted to rise from failure since her child kept reminding her to give the best facilities for her kid's needs. Her child is a university student. M said that she loves her children so much. M's kid is a student in elementary school, and it is the big reason she fights to start a new life. She tried to open her bakery with her small family. A desire to get through hard times is an incredible beginning for them. It can make them create a positive mindset, thoughts, and attitudes. Those are characteristics of women who have good resilience [19].

Being a single parent is not an easy thing to do in this twentieth century due to lifestyle, economy, health, and other aspects that influence wife into divorcement idea [20]. Everybody wants to fulfill their needs, whether it is family or close friend. Sometimes people have hopes when they are in difficult situations to increase their productivity. Hope is a primary term related to belief and desire to change to be better in the future [21]. In other words, they pray to make their wishes come true. It is also a source of strength to revive from futility, such as divorce. Every person has different expectations. There is one similarity; everybody always wishes good expectations for themselves. Those expectations are the source of strength for living a good life and putting a significant effort and spirit inside mind and heart. The five subjects have done it well.

$M$ had a big desire for her future. She said that if she prayed, she got a calm heart to live her life. It could also give her the power to be more productive, and she taught her kids about it. $\mathrm{M}$ wanted to be a good mother for her children and family. At the same time, she wanted to help others, while L wanted to make her business bigger than before. She had started it with her ex-husband when they were still together. $\mathrm{L}$ felt that it was such a great miracle for divorcing. She could be more grateful and patient to go through her life. T, J, and B had hoped to get a spouse who could accept them someday in the future. They wanted a responsible spouse who loves their family and has a good communication pattern.

Those five have unshakable belief to reach their dreams and hopes in the future. L 98\%, M 120\%, T 100\%, J 90\%, and B $95 \%$. These are the percentages of their confidence to reach their dreams. They are very optimistic about their future. It makes them gain a great amount of spirit and work harder than ever. An individual who has an optimistic mindset will be able to make it real forthcoming [22]. They could gain stable jobs to support their daily needs. It is proven that resilience can make them recognize that they will handle any difficult situations they face [23].

$\mathrm{M}, \mathrm{T}, \mathrm{J}, \mathrm{B}$, and $\mathrm{L}$ realize they are productive women, although they live without a husband. $M$ is grateful for being a lucky human being. She gets a precious moral value because of her patience and lives happily with her children. To sum up, it is imperative to have patience when unwillingness or disaster happens. $\mathrm{T}$ lives gratefully every day because this divorcement teaches her to accept herself. They said happiness has come after the divorcement with their husbands. It grows optimism mindset on their brains. In short, they deserve daylight after a long dark process in life.

One of the resilience aspects is optimism to do many things they want. A confident person can control their positive emotion, try to be happy and thankful no matter how hard the situation is. Additionally, she accepts it readily, even though it is inconvenient to change it [24]. $\mathrm{M}$ is the most patient subject. She never complained since she got divorced. It is normal when she feels hard to struggle alone, but she can handle it as long as she remembers God. It is the same with B when she feels stuck with her condition.

The five subjects have great optimism and strength to take moral values of any disasters. They have a big belief for a better future, even though many processes will come previously. Resilience will grow inside someone's mind after a tragedy happens. Hence, they can consider themselves as independent, productive, and dependable. Pride is someone's effort to reach something well [25]. Someone can reach a good pride based on how an individual envisages a process and find a way to reach the goal. All of the subjects are 
independent and do their best as a housewife.

\section{Conclusion and Recommendations}

\subsection{Conclusion}

According to the research, the five subjects are proven to have resilience. It can be seen from the cause of their divorcement process; they can improve themselves due to support from the people around them. All subjects are thankful for every disaster they faced. Patience is a symbol of strong, firm, and independent characteristics to live life after divorcement. Lastly, real pride is someone's strength to avow themselves as bold and strong individuals in reaching selfactualization. They need a long process to recognize that they are exempt and always think positively for their future.

\subsection{Recommendations}

Based on the five subjects' experiences, their background of divorcement are different. It is better if women protection organizations and religious court offices create a program to educate couples before they get married to prepare for any possibilities during their married lives. Besides, it is necessary to provide more information about marriage to minimize the amount of divorcement in the future.

The next researchers are also suggested to make a good research plan to anticipate unexpected factors such as distance. The researcher would like to thank all participants, advisors, and friends who supported him while writing the article.

The advantage of this research is that it collects detailed data on each subject in a relatively long time so that the results obtained are accurate with qualitative research standards. All research subjects can work together until the research process is complete. However, this study involved relatively few research subjects, amounting to five people, so it was less varied in terms of subject characteristics.

\section{References}

[1] Landquist J, Xu Z. Reinstitutionalizing families: life course policy and marriage in the military, Journal of Marriage and Family, vol. 76, no. 5, pp. 1063-1081, September 2014.

[2] Chao M.-R. Family interaction relationship types and differences in parent-child interactions, Social Behavior and Personality: An International Journal, vol. 39, no. 7, pp. 897914, August 2011.

[3] Malalu P, Alfred K, Too R. Determinants of use of modern family planning methods: A case of Baringo North District, Kenya, Science Journal of Public Health, vol. 2, no. 5, pp. 424-430, September 2014.

[4] Garvin V, Kalter, N, Hansell J. Divorced women, Journal Of Divorce \& Remarriage, vol. 21, no. 1-2, pp. 21-40, October 1994

[5] Malangvoice.com, Angka perceraian di kabupaten malang didominasi faktor istri gugat cerai, Malangvoice, 29 April
2019, [Online]. https://malangvoice.com/angka-perceraian-dikabupaten-malang-didominasi-faktor-istri-gugat-cerai $\quad[28$ November 2019]

[6] Scott S, et all. Reasons for divorce and recollections of premarital intervention: Implications for improving relationship education, Couple and Family Psychology: Research and Practice, vol. 2, no. 2, pp. 131-145, June 2013.

[7] Samulowtiz A, et all. rave men" and "emotional women": a theory-guided literature review on gender bias in health care and gendered norms towards patients with chronic pain, Pain Research and Management, pp. 1-14, February 2018.

[8] Ubaidi B. The Psychological and Emo on all Stages of divorce, Journal of Family Medicine and Disease Prevention, vol. 3, no. 3, Agust 2017.

[9] Lynn H. Concerns of the divorced women and impact on open health access, Florida Atlantic University, vol. 1, pp. 2-5, March 2018.

[10] Kucuksen K. Being a divorced woman in a patriarchal society: example of Konya, Necmettin Erbakan Universitesi, vol. 9, no. 44, June 2016.

[11] Barron L. Divorce and its effects on the development of children, University of Northern Iowa, 2010.

[12] Karela C, Petrogiannis K. Risk and resilience factors of divorce and young children's emotional well-being in Greece: a correlational study, Journal of Educational and Developmental Psychology, vol, 8, no. 2, pp. 12-13, June 2018.

[13] Ajaegbu W, et all. An empirical study on the causes and effects of communication breakdown in marriages, Journal of Philosophy, Culture and Religion, vol. 11, pp. 4-5, January 2015.

[14] Rajabizadeh, et all. The relationship between dysfunctional attitudes and communications skill of women with an addicted husband on the verge of divorce, Vesnu Publication, vol. 11, no. 1, pp. 51, Agust, 2018.

[15] Clayton R, Nagurney A, Smith J. Cheating, breakup, and divorce: is Facebook use to blame? Cyberpsychology, Behavior, And Social Networking, vol. 15, no. 10, pp. 717-720, October 2013.

[16] Frisby B, at all. Face and resilience in divorce, Journal of Social and Personal Relationships, vol. 29, no. 6, pp. 715-735, April 2012.

[17] Kartika Y. Resilience: Phenomenological study on the child of parental divorce and the death of parents, International EJournal of Advances in Social Sciences, vol. 3, no. 9, December 2017.

[18] Jakubiak B, Feeney B. Affectionate touch to promote relational, psychological, and physical well-being in adulthood: a theoretical model and review of the research, Personality and Social Psychology Review, vol. 21, no. 3, pp. 228-252, May 2016.

[19] Taormina R. Adult personal resilience: a new theory, new measure, and practical implications, Psychological Thought, vol. 8, no. 1, pp. 35-46, April 2015.

[20] Falana B, Bada F, Ayodele C. Single-parent family structure, psychological, social, and cognitive development of children in Ekiti state, Journal of Educational and Developmental Psychology, vol. 2, no. 2, October 2012. 
[21] Bahmani F, et all. The concepts of hope and fear in the Islamic thought: implications for spiritual health, Journal of Religion and Health, vol. 57, no. 1, pp. 57-71, January 2017

[22] Peters M, et all. Manipulating optimism: Can imagining the best possible self be used to increase positive future expectancies?, The Journal of Positive Psychology, vol. 5, no. 3, pp. 204-211, January 2010.

[23] Taylor Z, Conger R. Promoting strengths and resilience in single-mother families, Child Development, vol. 88 , no. 2, pp.
350-358, January 2017.

[24] Levina S. Psychological and social aspects of resilience: a synthesis of risks and resources saul, Clinical Research, vol. 5, no. 3, pp. 275, October 2015.

[25] Du H, King R, Chi P.). Self-esteem and subjective well-being revisited: The roles of personal, relational, and collective selfesteem, Plos One, vol. 12, no 8, Agust 2017. 